\title{
The problem of poor student education: Capital limitation \& decision making in higher education
}

\author{
Rika Kartika
}

Department Sociology, Faculty of Social and Political Sciences, University of Indonesia Email: rikakartika259@gmail.com

\begin{abstract}
This study aims to analyze how poor students learning problems are within the limitations of capital. And then, to explore how the decision making of poor students to continue higher education. The study was conducted at a private high school, East Jakarta, using a qualitative approach and case study method. Data collection techniques with interviews, observation, and study documents. The problem of low student education will continue as long as social class differences exist. The contrast of social class plays a role in almost all aspects of education, like learning achievement and educational choices differences. This study shows poor students' inability to get learning achievement because limited economic capital makes the other money little. Poor students who have low achievement don't pursue higher education. They chose to work early, appearing almost as an "unconscious strategy" to survive in an environment full of restrictions and shortcomings. This confirms the existence of poor student habitus that determines in explaining the disposition to work early. And then, poor students who have high achievements tend to go college but resisted the risk of not choose a favorite public university.
\end{abstract}

Keywords: Education, Poor Students, Habitus, Capital 


\section{Introduction}

The role of education in determining poverty is crucial. A country that has successfully overcome poverty is a country that is able to provide education to all its citizens. The scope of the DKI Jakarta Provincial Government, the percentage of Jakarta's poor population decreased in September 2018 by 3.55 percent, which meant 372 thousand people. Decreasing poverty becomes a breath of fresh air for the government in overcoming the factors that cause poverty, one of which is the low level of education (Kartasasmita, 1996: 240). The education assistance policy provided by the government to the poor can be seen as an effort to improve the education sector, primarily to provide equal opportunities for all levels of society to receive education. It was implemented through various educational assistance programs in DKI Jakarta, such as the Jakarta Smart Card (KJP) and the Jakarta Excellence Student Card (KJMU) which had an impact on increasing school participation.

The school participation rate is based on the age group in each level of education, namely elementary school (7-12), junior high school (13-15), high school (16-18), to college. In 2018 until 2019, school participation rates have increased at the junior high, high school to university levels. While the elementary school level decreased by $0.14 \%$. Even so, unlike in elementary, junior high and high school levels where the participation rate is above $50 \%$, the tertiary level is still below $50 \%$. At the high school level, students who through higher education with KJMU only amounted to 5,061 of the total recipients of the Jakarta Smart Card (KJP-Plus) 180,683 students from 2017 to 2019 stage 1 (Dinas Pendidikan Provinsi DKI Jakarta, 2019). Even though, SMA/SMK in DKI Jakarta contributes the highest level of $8.09 \%$ of SMA and $9.65 \%$ of SMK when compared to the diploma and university level of $4.81 \%$ (Badan Pusat Statistik, 2018).

Whereas in higher education can be a filter for parents to maintain the economic position of the family, and can simultaneously encourage economic efficiency and social mobility (Goldthorpe,1987). However, the conflict perspective sees education upside down as making a negative contribution to society. Every element in the social system has the potential to cause conflict in society. This conflict occurs because of differences in position or position between subsystems. Differences in position such as class differences impact on differences in opportunities to access educational facilities. On the other hand, educational institutions for the upper classes will be different from educational institutions for the lower classes of society. Rich families, most of whom have 
relatively high educational backgrounds, have the opportunity to take their children to quality schools. This also guarantees that later children from rich families will enter higher and higher quality schools. As a result, they will enter the campus and study programs that will guarantee graduates get jobs with high incomes.

In addition, class differences also have an impact on learning achievement. Like students in private schools labeled superior Islam generally has the ability to get achievement. The success of students in this school was approved through the ability of students to obtain national exam scores with an average graduation rate of $90 \%$ to $100 \%$ and the output distribution of their students managed to reach favorite domestic universities abroad (Lubis, 2008: 159-165). Whereas heterogeneous public schools in Madrasah Aliyah Negeri 1 Bandung, students from low socioeconomic groups are unable to get achievement at school, do not move up to class until they drop out (Supiana, 2008: 165). In addition to interest in learning, class differences also affect when making higher education decisions. Educational choices are based on classroom habitus that provides upper and lower limits in their aspirations, and conditions the cost-benefit analysis into decision making (Glaesser, 2013).

Rational choice theories and habitus are not mutually exclusive, they complement each other and provide a more complete picture of this social process (Vester, 2006). Seeing this reality, even though the obligation to study was increased up to high school, it certainly would not guarantee social mobility. The High education/universities are still selective and not all poor students can go to higher education. By using Bourdieu and Goldthrope's approach to see differences in educational choices in the context of socio-economic status students can provide novelty about the problem of educational inequality. The purpose of this study is to analyze the learning achievements of poor students amid the limitations of capital in the school field. Then, analyze the decision making of poor students to get higher education.

\section{Literature Review}

\section{The role of capital in learning achievement}

The field can be seen as a place of struggle for certain forms of capital. The field can be a space of struggle where human strategy is associated with affirming or enhancing their position with respect to defining capital in the field. Some forms of capital (such as educational qualifications, family 
background) can be utilized to maximize a position in an field so as to enhance trajectory. The main places for obtaining forms of capital that can be generally applied are schools. Habitus, the dominant social and cultural faction, acts as a multiplier of educational capital (Harker, et.all, 2009: 124). Capital is also seen by Bourdieu as the basis of domination (although not always recognized by participants). Various types of capital can be exchanged with other types of capital, which means that capital is 'exchangeable'. Capital can also be interpreted as a collection of resources (both material and non-material) owned by a particular person or group that can be used to achieve goals. Capital will determine position in social structures.

The concept of capital according to Bourdieu, there is social capital that refers to a set of actual or potential resources associated with the ownership of a network of mutual relations and / or mutual recognition that gives its members the support of shared capital. Cultural capital refers to a series of abilities or expertise of individuals including attitudes, ways of speaking, appearance, ways of getting along, and so on. Cultural capital can be manifested in three forms, firstly in the condition of developing cultural capital, it can be the disposition of the body and mind that is valued in a particular area. Second, in the objectified condition, cultural capital is manifested in cultural objects. As an object, cultural capital in this form can be owned by someone and can also be inherited or transferred to other people (the same as economic capital). Third, in the institutionalized condition, this cultural capital manifests the participation and recognition of educational institutions in the form of academic degrees and diplomas. Meanwhile, symbolic capital is a form of capital that comes from another type, which is recognized and recognized as something that is legal and natural.

\section{Decision Making in Higher Education for Poor Students in the Context of Habitus \& Rational Choice Theory}

Educational choices taken by children and parents from different class backgrounds are made at transition points in the system. Their choices tend to strengthen social class differentiation. Hatcher (2006) offers two opposing perspectives to study this phenomenon. First, rational choice theory (RAT). Rational action theory regards it as the result of rational utilitarian choices made by actors who occupy different classes in unequal societies. Second, Bourdieu's perspective. From the perspective of cultural reproduction, it can 
be explained in terms of cultural processes which unwittingly bring goals into conformity with their social position. By bringing dialectical habitus, institutions and rational actions can further explain the scenario of educational choices. A comprehensive agency theory in the field of education needs to maintain the power of the culturalist paradigm while creating space within it for rational strategic decision making, both for non-utilitarians and utilitarians. In the context of this research, it is interesting to bring these two approaches to study higher education decision making by students who have different class backgrounds.

\section{Habitus (Bourdieu)}

Bourdieu explains how action is a product of the relationship between habitus (which is a product of history) and the field, which is also a product of history and at the same time, a product of the power of the field. Habitus refers to a set of dispositions that are created and formulated through a combination of objective structures and personal history. Disposition is obtained in various social positions within an field, and implies a subjective adjustment to that position. Habitus is a place for internalizing reality and externalizing internality. This indicates a dialectical relationship between objective structures and the cognitive and motivational structures that they produce and tend to reproduce them. Habitus is objectively adjusted to the conditions in which it is formed (Jenkins, 1992: 115). Such objective conditions continually instill various dispositions of character, which in turn give birth to aspirations and practices that are in line with objective conditions. Therefore, according to him, habitus changes in each sequence or recurrence of events in a direction that seeks compromise with material conditions. However, this compromise is inevitably biased, because perceptions about the objective conditions themselves are born and filtered through habitus. This implies that habitus itself is no more "unchanging" than the practice that it helped to structure (Harker, et.all, 2009: $15)$.

In addition, related to the next educational choice. The fact that habitus helps to understand how a student's habitus forms the trajectory of his choice of course. The concept of habitus explicitly combines the existence of individual agencies and the mechanisms by which dispositions, structured by social constraints, are related to external behavior. The desired action for habitus may be accompanied by a strategic calculation of costs and benefits which at the conscious level tends to carry out operations carried out by habitus in its own way. According to Bourdieu, the outward appearance of decision 
making could be (a) a shadow or reflection of what the habitus did, whether done before or simultaneously, (b) a choice which in certain situations is part of the habitus, not an autonomous or elected process (c) illusion as long as the principle of operation is inhibited and originates from habitus. Therefore, it is important to remember that habitus itself controls this choice. We can always say that individuals make choices, as long as we do not forget that they did not choose their chosen principles (Harker, 1990: 112).

\section{Relative Risk Aversion (Breen \& Goldthrope)}

The Breen-Goldthorpe Model of Relative Risk Analysis is used to explain inequality at the level of educational attainment (Breen and Goldthorpe, 1997). This model, builds on maximum decision rules (to maximize the worst outcome), which implies that individuals from disadvantaged backgrounds are more risk averse, and are largely consistent. Individuals from disadvantaged backgrounds value a higher rate of return and, therefore, accept the risk of accessing this return. However, individuals from disadvantaged social backgrounds tend to exchange high returns to minimize the risk of returns. In Relative Risk Aversion theory, the criterion of rationality that guides educational decision making is the desire to avoid decreased social class mobility (Breen and Goldthorpe, 1997). In Relative Risk Aversion theory, education consists of instrumental means to minimize the risk of entering lower social classes than their parents. They weigh the potential utility that comes from various education choices against education costs (real costs and previous lost income) and subjective probabilities of failure to complete the level of education ("risks" associated with educational investment).

The fact that children who come from higher social circles more often go to school at a higher level (controlling ability) is explained by the fact that they need more education to ensure the maintenance of social class. In their education making decisions, families will consider the costs and benefits of educational options compared to leaving school, and leaving school early is an expensive choice for children who come from higher social classes, because they will not be able to meet the goals of care class. Children with lower social backgrounds must be more ambitious than children with higher social backgrounds to continue schooling, especially the transition to higher education. Children with lower social backgrounds need a higher probability of success than children with a higher social background when deciding to continue schooling (Goldthorpe 1996, 2000: chapter 11; Breen and Goldthorpe 1997). 
According to the Relative Risk Aversion theory, the reason why class inequality in achieving educational attainment is because young people from different social class backgrounds need different levels of education to maximize the possibility of maintaining their social class position. Because pursuing education is a way to secure social status. The desire to avoid decreased mobility leads to different choices of education in different classes. Students from the upper class are encouraged to choose the high path, which is necessary if they want to maintain their social position, while students from the lower class choose the low path, which is sufficient to maintain their social position. Finally, the rational choice model leads us to the fact that social reproduction is mediated in part by differences in educational choices (Breen and Goldthorpe, 1997).

\section{Methods}

This research was conducted in early January to March 2020 in one of the Private High Schools, East Jakarta with using a qualitative approach methods and case study. Qualitative approach is the process of understanding the study of research problems related to the meaning imposed by individuals, or groups on a social problem (Creswell, 2013: 59). Data collection techniques using observation, interviews and study documents. The author makes note of the field by observing as a participant. That way, the writer can understand where poor students carry out education in schools with limited capital. Field notes and don't forget to use important events needed to support the study in this research. In addition, in-depth interviews are used by the author to uncover poor student learning problems in the context of capital and habitus.

In starting the interview, the writer identifies poor students with high achievements and poor students with no achievements in 12th grade. And then, study documents through school AD / ART archives and student legers. By using a qualitative approach, data analysis will rely on data sources obtained through primary data and secondary data. Primary data, such as information obtained through the field will be analyzed through the following steps : (1) making interview transcripts to facilitate researchers in mapping information, (2) carrying out the analysis process according to the design made by researchers, (3) contextualizing the data in order to identify different aspects in establishing the consumption in information, (4) the report is explained descriptivelyanalytically with the intention of the information described and developed 
based on the concepts used in the study.

\section{Results and Discussion}

\section{Capital Limitations in Poor Student Learning Problems}

The inability of poor students to achieve learning achievement is inseparable from their limited economic capital. Bourdieu argues that limited economic capital makes poor students as agents of difficulties in accumulating and converting into social, cultural and symbolic capital in the field of school. Limited economic capital also limits student ownership of other capitals. This reality makes the position of poor students in the field of school is weak. As is the case with poor students initialing AR. In the covid-19 pandemic, the Ministry of Education and Culture indeed instructed for Distance Learning to be supported by technology. The school implements one application, the google classroom. This is of course demanded to approve mobile phones, laptops and internet connections. AR have a cellphone but doesn't really understand anything related to technology. He never attended a Computer Training Institute (LPK) held by the school. Even though the teacher is sufficient in accommodating students, it still cannot attract students to attend LPK diligently and one of them is AR. Whereas through LPK, AR can be more adept at operating computers.

The limited economic capital of AR has an impact on the ownership of limited cultural capital. From elementary school, junior high school to high school, AR is not very good in English. In addition, this is also seen from the ownership of modern objects (objectified state) such as mobile phones and laptops. The limitations in having a laptop made AR unable to operate a computer, so when the school held LPK, AR was not so enthusiastic because it was far from these modern objects. While institutional capital (an institutionalized country) is also not owned by AR, it's not active in extracurricular so there is no certificate of appreciation. The absence of economic capital also impacts on the lack of non-physical capital. Despite economic and culture capital is inadequate, he has enough social capital in a network of friends. The limitations of AR parents because of their educational background, who are only junior high school graduates, make parents less interfering in helping him when experiencing learning difficulties. He tends to ask friends and rather rely on his friends. That is, when there are homework and assignments, he is more inclined to wait for the work of his friends than to discuss the answer. So this has a negative impact on his fighting power in learning. 
As with AR, limited economic capital makes cultural capital owned by $\mathrm{AD}$ also weak, such as modern and prestigious objects (objectified state) that are very far from AD. AR's cellphone is also not a prestigious branded cellphone but that can be used for the internet only. He doesn't have laptops too, so if there is a task and homework, he only relies on mobile phones. While institutional capital (institutionalized state) is also not owned, it is not very active in following extracurricular activities. Even though he follows football, he doesn't regularly practice because it will spend money, even though he was very interesting to football from childhood.

His interests and talents are hindered by limited economic capital. AD's inactivity in training made him not participate in the tournament so there was a minimum of award certificate. The absence of economic capital also impacts on the lack of non-physical capital (embodied state). This can be seen from the figure of AR who is less disciplined, less polite and violates school rules. Although economic and cultural capital is limited, it tends to have good social capital that is friends with those who have a better level of life. when he has difficulty learning and his mother who is only a junior high school graduate cannot help, so he often asks his friend as well as looking on the internet. Unlike $\mathrm{AD}$ and $\mathrm{AR}$ which have adequate social capital in the economic limitations, $\mathrm{RQ}$ has friendship relationships that exist in the scope of his work.

This is because in addition to being a student, he also works as an online motorcycle taxi driver. His father's non-permanent income as a vehicle repair shop, he worked late into the night at $02.00 \mathrm{a} . \mathrm{m}$. This has an impact on low learning motivation seen from how he is more enthusiastic about making money than learning. He doesn't care about homework or assignment tomorrow. Even so, with the results of his work, he earns Rp. 100,000, - a day and a month can get Rp. 3,000,000. From the results of the ojek, he can buy modern objects such as cellphones, laptops and even the remaining money can be saved as much as Rp. 50,000.

This means that cultural capital in possession of modern objects (objectified state) is fulfilled. Even so, he is rarely actively involved in school activities such as extracurricular activities. Even though at the beginning of the semester in the 10th grade, he joined volleyball extracurricular activities, but after starting work he started to leave it. Thus, cultural capital (institutionalized state) is weak. Then, cultural capital is the lack of non-physical capital (embodied state) which can be seen from how he became an arrogant and less disciplined person. DF that doesn't have limited economic capital is not surrounded by 
modern objects (objectified state) such as mobile phones that are used without brand names that can only be used for telephone and message.

He also did not actively participate in extracurricular activities that initially took part in basketball. he did not participate in the training organized by the school, the Computer Training Institute (LPK). Thus, cultural capital (institutionalized state) is also weak. Limited economic capital makes minimal non-physical capital (embodied state). This is seen from how his life behavior is not disciplined, in addition to not doing the task, also the absence and tardiness in school.

\section{The tendency of poor students who less achievements don't take higher education}

The education problem of poor student is not only related to the inability to compete in school, but the low chance of poor students to take high education. This is related to data from the DKI Jakarta Provincial Education Office which shows the total number of poor students receiving KJP-Plus at the high school level, namely 180,683 students, only 5,061 students to take higher education with KJMU. Meanwhile, according to Goldthorpe (1987), education at the higher education level can be a filter for parents to maintain the economic position of the family, and can simultaneously encourage economic efficiency, social justice, and social mobility. This relates to the typology of Robert K Merton's function, social mobility as a form of the latent function of educational institutions which means that a person can raise his social status by taking education to a higher level or more easily, it can be said through education that poor families can get out of poverty and changes in social status.

The private schools which have heterogeneous students' socio-economic backgrounds, where almost $50 \%$ of students are KJP-Plus recipients, this school is considered to be able to provide opportunities for poor students in terms of disclosure of information on admission into state universities. One of the activities that the school has developed is to bring in alumni that have been accepted by state universities to socialize related to the selection process, tips to redeem state universities and so on. Although in this case the school has carried out its role to motivate students in pursuing higher education. It was not enough to encourage some of the following poor students to go to college. Like AR who is not interested in college and thinks that college will be in vain. Besides not wanting to go to college, even though AR has social capital with 
friends in his school who tend to come from adequate economic capital. Then, almost most of his friends said that they wanted to go to college even though they didn't have to go to state universities, it was not enough to encourage the same intention towards AR.

Werfhorst, et.all (2007: 403) revealed that children from all social backgrounds are more or less equally concerned with achievement and at least the same grade as their parents. This is a confirmation of one of the core assumptions of Relative Risk Aversion Theory. This indicates that it does not mean that children from low educated backgrounds are more concerned about mobility than children from high educated backgrounds. The problem of mobility is indeed relative to the socio-economic background of children. Like $\mathrm{AR}$, even though it comes from an inadequate socio-economic background it also does not make him concerned about the condition of his parents, whose income is uncertain every day because it relies only on the results of satay sales.

AR tends not to prioritize schools such as not wanting to get echievment and not wanting to pursue higher education even though there is educational assistance such as the KJMU or scholarships. This indicates that compared to upper class children who choose risky options because this will bring them to the upper classes. Conversely, lower class children tend to choose options that are not too risky because they are satisfied with the achievement of their class work (Breen and Goldthorpe 1997: 283).

Although rational choice perspectives offer alternatives to cultural theory and still dominant norms about educational inequality, such as Bourdieu's theory of cultural reproduction (Werfhorst, 2007: 392). Bourdieu does not offer explicitly about decision making or the secondary effects of class differences. Then, proponents of rational choice perspectives have recognized the potential role of class-cultural influences in primary effects, generally proponents of rational choice perspectives argue that this is not sufficient in relation to decision making (Boudon, 1974).

However, from the case of $\mathrm{AR}$ and four other students who will be presented later, it seems necessary to include the concept of Bourdieu in particular the idea of habitus. Agents who do that don't have to be guided by a conscious and deliberate search for satisfaction of these proposed interests as goals. The fact that they actually do not need to be involved in rational calculations to achieve the goals that best suit their interests. As for what is done by following dispositions that are tailored to their position, "naturally" results in practices that are adapted to the situation (Bourdieu 1990b: 108). 
Just like AR who is not interested in college, DF is not interested in college because he is only wants to open motorcycle workshop. Even though the school has conducted socialization related to college entrance selection, then if related to financial problems there have been many educational assistance programs like KJMU, but he remains to choose work. This is as Breen and Goldthorpe (1997) state that individuals with lower class backgrounds have lower incentives to pursue higher education compared to people from high social backgrounds. So 'relative risk aversion' is further distinguished into 'strategies from above', where middle class students aim to maintain their socially benefited positions by making educational choices that will maximize their chances of entering the next middle class work. Then the 'bottom-up strategy' where lower-class students make the decision to pursue qualifications only to the point that this will minimize the risk of experiencing unemployment.

The low incentives of higher education to poor students can be explained through the concept of habitus Bourdieu which means individuals construct the world around them. Habitus also includes one's knowledge and understanding of the world, which contributes itself to the reality of that world. Therefore, one's knowledge has constitutive power, the ability to create forms of world reality (Harker, et.all, 2009: 46). This is like DF's view of education as a place for smart people. Indeed at school, DF is often involved in learning problems and school discipline. For him, the channel for social mobility isn't through education but through entrepreneurship.

Unlike most students in general, RQ in high school has worked as an online motorcycle taxi. Previously, he also had time to leave school with the problem of absence until finally starting school again. This is as Willis stated that students from the lower levels of society want to leave school to find work (Willis, 1997; Willis in Haralambos and Halborn, 2004: 702-703). Regarding university entrance selection, he also considers this complicated. This also refers to the mechanism of relative risk aversion, for middle class children it implies choosing risky options because this will bring them to the upper classes. Conversely, working class children tend to choose options that are not too risky because they are satisfied with the achievement of working class work (Breen and Goldthorpe 1997: 283).

However, in this case RQ actually wants to change fate but not through school. This is why the RQ for three years at school often has problems in low motivation to learn. Then, other things can't be separated how the family formed it. From his statement, RQ can be an online motorcycle taxi with 
reference to his brother. Some of his brothers tend not to succeed in education. Such objective conditions continually in still various dispositions of character, which in turn shape aspirations and practices that are in line with objective conditions. Therefore, habitus in this case forms the trajectory of RQ education choices for not being interested in college.

\section{Poor Students who have Achievements in Higher Education Decision Making}

In opening opportunities for poor students to get higher education, the central government and regional governments have issued many educational assistance programs such as Bidikmisi, LPDP, and KJMU. However, this access is still difficult for poor students to penetrate especially in order to be accepted by universities in the QS Graduate Employability Rankings 2020 list in Asia. This is due to the fact that very few KJMU recipient poor students are registered at favorite universities, which is $3.93 \%$. A total of 5,061 KJMU recipients scattered from 94 state universities in Indonesia, around 31\% were students from Jakarta State University, followed by Syarif Hidayatullah State Islamic University with a percentage of $15.25 \%$. Whereas it is known that universities can be a benchmark in getting a job later (DKI Jakarta Education Agency, 2019).

The problematic education of poor students in the context of the description can be seen through one of the rational choice perspectives that influences educational decision making, namely the relative risk aversion from Breen and Goldthorpe (1997; Goldthorpe 1996). Breen and Goldthorpe consider that children take the social position of their parents as a reference for their own aspirations. The relative risk aversion mechanism states an important goal in educational decision making is to avoid downward mobility. One will pursue a minimum educational career to realize this goal. Then, people tend to struggle for the level of education and social position that is at least as good as the position of their parents. (Werfhorst, 2007: 392).

The difference in educational choices in the context of students' social backgrounds, is a Goldthrope starting point where the choice strategies pursued by middle class and working class decision makers will differ as they strive to achieve this goal. So 'relative risk aversion' is further distinguished into 'strategies from above', where the middle class aims to maintain their socially benefited by making educational choices that will maximize their chances of entering the next middle class work, and 'strategies from below' where the working class 
makes the decision to pursue qualifications only to the point that this will minimize the risk of experiencing unemployment. For Goldthorpe, this is a key element that forms the path of children's education, and consequently their highest achievement.

As DM who has a father as a glass bottle opener. There are a number of things that DM considers when deciding on a higher education plan. Although he has always been ranked in the top five class, this inevitably makes him optimistic in achieving his goals. At the parallel ranking level, he is registered as a participant in the university entrance invitation. At SNMPTN, he chose UIN Gunung Jati with a major in electricity. Then, he chose PNJ with the same majors, but both didn't qualify. As told by DM by seeing the family's economic capital is limited and there are still younger siblings whose schooling is a consideration for continuing higher education. DM's father, who did not want government assistance and DM who found it difficult to take the scholarship route, was enough to create a DM dilemma for this problem.

For Goldthorpe, the role of family cultural resources in shaping educational attainment was not rejected, but he stressed that this was only a small part. The most important thing in his view is that family resources, especially the economy, play a fundamental role in joint decisions between children and their families is an important stage. Even though he knew there was a scholarship path, DM felt it was very difficult for him to travel. Then, it would be better for him to take the risk to just work which happened to be his friend's offer so he had to abandon his next education plan.

This is as Goldthrope states that individuals from disadvantaged backgrounds are more risk averse, and largely consistent. Individuals from disadvantaged social backgrounds tend to exchange high returns to minimize the risk of returns. In contrast to individuals from disadvantaged backgrounds, individuals from disadvantaged backgrounds assess higher rates of return and, therefore, accept the risk of accessing these returns (Hallsten, 2010: 812). Unlike $\mathrm{DM}, \mathrm{SN}$ is the student who always gets first place in his class. $\mathrm{SN}$ comes from an adequate economic background and is not reluctant to choose medical majors that are considered expensive for their education costs. He also has an alternative private campus if not accepted at public universities. Then, unlike $\mathrm{SN}, \mathrm{FH}$, which has limited economic capital and is ranked in both class 10, 11 and 12, she doesn't accepted in SNMPTN and SNMPN. In SNMPN, FH chose management and accounting majors. The considerations chosen by FH based on the following explanation: 
"If management is rich in creating jobs, just when I ask their parents, just follow my choice. I also searched for questions about majors and counselors with counselors about the majors. When alumni went to school, I was very interested to hear about the information, and there were alumni who got at UI, well, I was thinking why I chose a good campus, what was important was getting the opportunity".

In making educational decisions, FH doesn't take risks on the choice of favorite state universities. Same is the case with FH, AS who always gets a class ranking in high school didn't take the risk. Meskipun ibunya hanya pedagang, dia masih memiliki tekad untuk melanjutkan pendidikan tinggi. She isn't like DM will try to use KJMU for his education costs. If she doesn't get a state university, she will choose a private campus with affordable education costs. Children with lower social background must be more ambitious than children with higher social background to continue schooling, especially the transition to higher education. Children with lower social backgrounds need a higher probability of success than children with a higher social background when deciding to continue school (Goldthorpe 1996, 2000: chapter 11; Breen and Goldthorpe 1997).

\section{Conclusion}

The results showed two things in looking at the education problems of poor students. The first thing is related to the application of various capital (social, economic, symbolic and cultural) to poor students in the school field. This is because the application of poor student capital turns out to produce differences in learning achievement. Limited economic capital makes students also limited other capital. This reality makes the position of poor students in the school is weak. In addition, what is of concern is that groups of poor students who don't have a tendency to have social capital with those who underestimate education, such as being involved in school rules, sometimes truant, not doing assignments and even having social capital with workers and unemployed adults. It is very different from the group of students who have limitations, but can get learning achievement. What is interesting is the role of peer social capital in fostering a spirit of learning. Poor students who get achievment tend to be friends with those who are concerned with school, such as attending school regularly, getting good grades. The second thing is about decision making of poor students to get higher education. 
Then, interesting thing also related to the dilemma of higher education for poor students also afflicts poor students with high achievements. The dilemma is related to the choice of state universities as their goal. Although financial assistance is trying to be provided through KJMU which doesn't limited the choice of the high education, the reality is that poor students are reluctant to choose their favorite higher education. Then, if they do not get a favorite public university, they will look for private schools that are cheap. There are even poor students with high achievement who work directly because they can't compete. In contrast, middle-up students tend to maximize risk in order to obtain the state tertiary institution. This is related to differences in educational choices in the context of students' social backgrounds, according to Goldthrope (1997) namely the choice strategies adopted by middle-class and working-class decision makers will be different when they try to achieve this goal.

\section{REFERENCES}

Boudon, R. (1974). Education, opportunity and sosial inequality. New York : Wiley. Bourdieu, P. (1990). The logic of practice. Cambridge: Polity Press.

Breen, R. \& Goldthrope, H. J. (1997). Explaining educational differentials: Towards a formal rational action theory. Sage Publications. 9(3): 275305. DOI: $10.1177 / 104346397009003002$

Creswell, J. W. (2013). Qualitative inquiry $\mathfrak{B}$ research design, choosing among five approaches, Third Edition. SAGE Publications.

Glaesser, J. \& Cooper, B. (2013). Using rational action theory and Bourdieu's habitus theory together to account for educational decision making in England and Germany. Sage Publications. 48(3) 463-481. DOI: $10.1177 / 0038038513490352$

Goldthorpe, J. H. (1987). Sosial mobility and class structure in modern Britain(2nd ed.), Oxford: Clar-endon Press.

Goldthrope, J. H. \& Breen. R. (1997). Explaining educational differentials: Towards a formal rational action theory. Sage Publications London.

Goldthrope, J. H. (1998). Rational action theory for sociology. Blackwell Publishing. Grenfell, M. (Ed). (1998). Bourdieu and education. USA: Falmer Press, Taylor \& Francis Inc.

Haralombos, M et.all. (2000). Sociology themes and perspective: Sixth Edition. 
The problem of poor student education: Capital limitation \& decision making ... (Rika Kartika)

London: Collins Education.

Harker, R. Mahar C., \& Wilkes, C. (2009). (Habitus x Modal)+Ranah=Praktik. Bandung: Jalasutra

Hatcher, R. (2006). Class differentiation in education: Rational Choice. Routledge.

Jenkins, R (1992). Pierre Bourdieu. London: Routledge.

Kartasamita, G. (1996). Pembangunan untuk rakyat; Memadukan pertumbuhan dan pemerataan. Jakarta. CIDES

Lubis, H. (2008). Pertumbuhan SMA Islam unggulan di Indonesia: Studi tentang strategi peningkatan kualitas pendidikan. Jakarta: Balitbang dan Diklat Departemen Agama RI

Ritzer, G. \& Godman, D. J. (2004). Teori sosiologi modern: Edisi keenam. Jakarta: Kencana.

Supiana. (2008). Sistem pendidikan madrasah unggulan di Madrasah Aliyah Negeri Insan Cendekia Tanggerang, Madrasah Aliyah Negeri Bandung dan Madrasah Aliyah Negeri Darussalam Ciamis. Jakarta: Balitbang dan Diklat Departemen Agama RI.

Van de Werfhorst, H. G., \& Hofstede, S. (2007). Cultural capital or relative risk aversion? Two mechanisms for educational inequality compared 1 . The British journal of sociology, 58(3), 391-415.

Willis, P. (1997). Learning to labor: How working class kids get working class jobs. New York : Columbia University Press.

http://statistik.jakarta.go.id/kartu-jakarta-mahasiswa-unggul-kjmu/ Accessed 20/5/2020

http://statistik.jakarta.go.id/sebanyak-55-penerima-kjp-plus-merupakanpeserta-didik-sekolah-dasar-sd/ Accessed 20/5/2020 
Journal of Social Studies (JSS), Volume 16, Number 1, 2020: 1-18 